\title{
Comparative Analysis of Lumpsum Contract and Unit Price Contract Risk Using Analytical Hierarchy Process Method (Case Study of Contractors in Bekasi)
}

\author{
Handayani Anjas dan Irma Tiara \\ Faculty of Engineering, Mercu Buana University, Indonesia \\ anjas_handayani@yahoo.com, tiarairma98@gmail.com
}

\begin{abstract}
Bekasi Regency Government gives priority in infrastructure development. According to the Central Statistics Agency for West Java Province, the population of Bekasi was 2,344,871 people in 2018. The Bekasi Regency Government will build roads in 28 locations, one of which is to improve the existing infrastructure in Bekasi. In every business, there will always appear two contradictory things which are profit and profit, including in the construction services business. Construction activities can be completed when meeting all the objectives that have been set, following the agreed costs, and meet the quality that has been previously agreed upon. The purpose of this study is to study agreements regarding lump-sum contracts and unit price contracts. This research method uses the Analytical Hierarchy Process Method. The research process starts with creating problems and making hierarchical arrangements. The hierarchical structure consists of three things namely objectives (level I), criteria (level II), and alternatives (level III). Once organized, the hierarchy will be attended by using a questionnaire for 30 respondents. After the data is obtained, the data is tabulated, then the paired frame is searched, move in pairs, and the priority weights. The results of the analysis by the AHP method were obtained in a construction project in Bekasi City, the factor of using Lumpsum contract was more influential compared to the contract Unit price with a ratio of 52.01\%: $47.99 \%$.
\end{abstract}

\section{Keywords}

lump-sum contracts, unit price contracts, analytical hierarchy process methods.

\section{Introduction}

Bekasi Regency Government gives priority in infrastructure development. According to the Central Statistics Agency for West Java Province the number of residents of Bekasi infrastructure such as building construction, roads, irrigation, and others with field actors the business is the contractors who have experienced in the construction field. In implementation of construction projects, contracts is a standard bond between the project owner (owner) with the executor / constructor as service provider. During the auction stage usually The owner has already mentioned the type of contract that is will be used. Two types of contracts are frequent used in Indonesia is a contract lumpsum (fixed price) and unit price contract (unit price).

According to Perpres No. 16 Article 27 paragraph 3 and 4 of 2018 that the lump sum contract viz contract with the scope of work and the exact amount and remains within the time limit certain with the provisions of all risks fully borne by the provider, output-oriented, and payment oriented based on the product / output stage which is generated according to the contract. While a unit price contract is a contract of service other construction goods / work / services with fixed unit price for each unit or elements of work with technical specifications certain of the completion of all work within the time limit set with terms of volume or quantity of work still estimated at the time of the contract signed, payment based on results joint measurement of volume realization work, and the final contract value is determined after all the work is done.

\section{Methodology}

To achieve this research objective, the study is divided into several stages, including:

a. Determination of paired matrices

b. Paired matrix normalization 
c. Paired matrix consistency test

d. Calculate a consistent index, CI (consistency index) using the equation $C I=\frac{t-n}{n-1}$

If $\mathrm{CI}=0$ then matrix $\mathrm{A}$ is consistent

If $\frac{C I}{R I_{n}} \leq 0,1$, then matrix $\mathrm{A}$ is quite consistent

If $\frac{C I}{R I_{n}}>0,1$, then matrix $\mathrm{A}$ is very inconsistent

RIn, the random index is the average value of CI chosen randomly in matrix A. A table of the several RIn values is given in table 3.6 below:

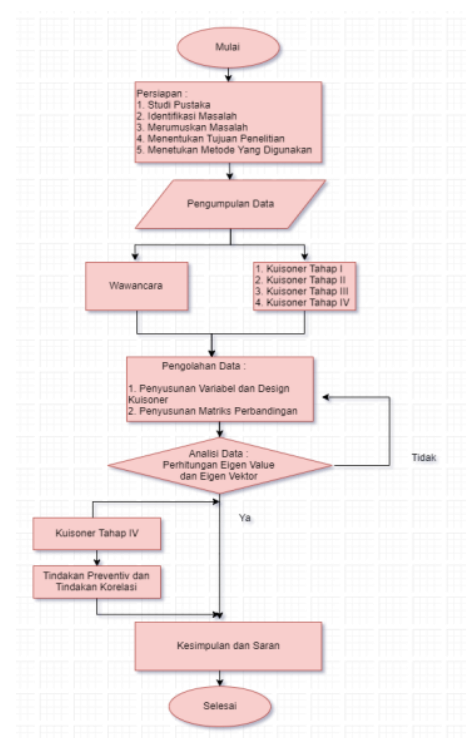

(Source: Researcher's processed, 2019)

Figure 1. Research Flow Diagram

Table 1 Random Index on several values of $n$

\begin{tabular}{|c|c|c|c|c|c|c|c|c|c|c|}
\hline $\begin{array}{c}\text { The order of } \\
\text { the matrix }\end{array}$ & 1 & 2 & 3 & 4 & 5 & 6 & 7 & 8 & 9 & 10 \\
\hline RI & 0 & 0 & 0.58 & 0.9 & 1.12 & 1.24 & 1.32 & 1.41 & 1.45 & 1.49 \\
\hline
\end{tabular}

Source: Author's Processed Results, 2019

\section{Result and Analysis}

In the results of the first stage data collection, namely by distributing the stage I questionnaire to experts / experts. The experts / experts provide responses, corrections, input, addition and subtraction on each of the initial risk variables that are asked for their opinions. These improvements include reducing unrelated or invalid variables on the research topic, and corrections to the grammar of the writing presented in the questionnaire to be understood by respondents.

In the next stage of the questionnaire the second stage of data collection researchers conducted a questionnaire questionnaire containing variable results from the stage I data collection to three selected respondents. The purpose of this phase II sampling is to ensure the format of the risk variable along with the sentences is clear and can be easily understood by respondents

In the Phase III questionnaire, questionnaires were distributed to 30 respondents who had been distributed to those involved in the Cimanggis-Cibitung Toll Ways Project Section 2 and MM2100 Underpass Project. 


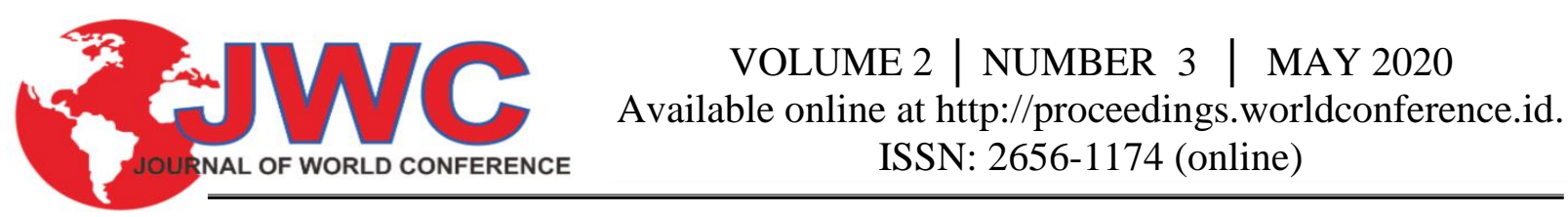

\section{A. Risk Level Assessment}

After tabulating the data from the questionnaire, a variable reduction is carried out by multiplying the frequency and impact according to the respondent's answers to each variable to get the value of the risk level. From the results of the assessment of the risk level, five variables were selected with the highest risk level for each aspect of both the lump sum contract and the unit price contract which will be used in subsequent risk analyzes. There are differences in the level of risk for lump sum contracts and unit price contracts so that the combination of the highest risk factors obtained in the two contracts results in 21 risk factors with the description of rank $1=$ very influential; 2 $=$ more influential; $3=$ influential; $4=$ less influential; and $5=$ no effect as shown in the following table.

Table 2. Risk Level Assessment

\begin{tabular}{|c|c|c|c|c|}
\hline \multirow[t]{2}{*}{ Ranking } & \multicolumn{2}{|r|}{ Lumpsum Contract } & \multicolumn{2}{|r|}{ Unit Price Contract } \\
\hline & Variable & Risk Factor & Variable & Risk Factor \\
\hline \multicolumn{5}{|c|}{ Cost } \\
\hline 1 & $\mathrm{X} 16$ & $\begin{array}{l}\text { Changes, work schedule delays on } \\
\text { request or interrupt owner. }\end{array}$ & $\mathrm{X} 8$ & Government policy. \\
\hline 2 & $\mathrm{X} 11$ & $\begin{array}{l}\text { Weaknesses in controlling the } \\
\text { receipt of payments, for example } \\
\text { payments for jobs that are not } \\
\text { timely. }\end{array}$ & $\mathrm{X} 6$ & Rework caused by a design change. \\
\hline 3 & $\mathrm{X} 4$ & $\begin{array}{l}\text { The nature of the project in the } \\
\text { scope of work is still new with a } \\
\text { certain level of construction } \\
\text { difficulty. }\end{array}$ & $\mathrm{X} 15$ & $\begin{array}{c}\text { Performance of suppliers and } \\
\text { subcontractors. }\end{array}$ \\
\hline 4 & $\mathrm{X} 1$ & $\begin{array}{l}\text { Differences in field site conditions } \\
\text { with those stated in the contract. }\end{array}$ & $\mathrm{X} 10$ & $\begin{array}{l}\text { The excess amount of material } \\
\text { delivered (waste) is greater than } \\
\text { expected. }\end{array}$ \\
\hline 5 & $\mathrm{X} 2$ & $\begin{array}{l}\text { Procurement of additional jobs } \\
\text { less (change order). }\end{array}$ & $\mathrm{X} 14$ & HR Professionalism \\
\hline \multicolumn{5}{|c|}{ Quality } \\
\hline 1 & $\mathrm{X} 21$ & $\begin{array}{l}\text { Project quality testing is not } \\
\text { routine and does not follow } \\
\text { established rules }\end{array}$ & $\mathrm{X} 22$ & $\begin{array}{l}\text { Procedures and consistency of } \\
\text { rejection of work that does not meet } \\
\text { quality requirements. }\end{array}$ \\
\hline 2 & $\mathrm{X} 26$ & Experience. & $\mathrm{X} 32$ & $\begin{array}{l}\text { Environmental conditions around } \\
\text { the time of the project. }\end{array}$ \\
\hline 3 & $\mathrm{X} 22$ & $\begin{array}{l}\text { Procedure and consistency of } \\
\text { rejection of work that does not } \\
\text { meet quality requirements. }\end{array}$ & $\mathrm{X} 26$ & Experience. \\
\hline 4 & $\mathrm{X} 27$ & Claim. & $\mathrm{X} 21$ & $\begin{array}{l}\text { Project quality testing is not routine } \\
\text { and does not follow established } \\
\text { rules. }\end{array}$ \\
\hline 5 & $\mathrm{X} 33$ & $\begin{array}{l}\text { Environmental conditions around } \\
\text { the time of the project. }\end{array}$ & $\mathrm{X} 33$ & $\begin{array}{l}\text { Environmental conditions around } \\
\text { the time of the project. }\end{array}$ \\
\hline \multicolumn{5}{|c|}{ Time } \\
\hline 1 & $\mathrm{X} 41$ & Design change. & $\mathrm{X} 39$ & Project completion time. \\
\hline 2 & $\mathrm{X} 36$ & $\begin{array}{l}\text { Accuracy of schedule based on } \\
\text { implementation compiled at the } \\
\text { beginning of planning. }\end{array}$ & $\mathrm{X} 36$ & $\begin{array}{l}\text { Accuracy of schedule based on } \\
\text { implementation compiled at the } \\
\text { beginning of planning. }\end{array}$ \\
\hline 3 & $\mathrm{X} 44$ & Approval and Permission. & $\mathrm{X} 35$ & Workforce Expertise. \\
\hline 4 & $\mathrm{X} 38$ & $\begin{array}{l}\text { Sanctions for late project } \\
\text { implementation. }\end{array}$ & X37 & Fixed schedule. \\
\hline 5 & X34 & Resource. & $\mathrm{X} 40$ & $\begin{array}{l}\text { Ease of providing material, } \\
\text { equipment and methods used. }\end{array}$ \\
\hline
\end{tabular}

Source: Author's Processed Results, 2019 


\section{B. Arrangement of Hierarchy Structure}

Based on the assessment of risk levels above, risk factors are then further analyzed using the AHP method which starts with the stages of the preparation of the hierarchical structure. The goal to be achieved now is to determine the dominant risk factors in lump sum contracts and unit prices in terms of cost, time and quality of the project as shown in the following figure.

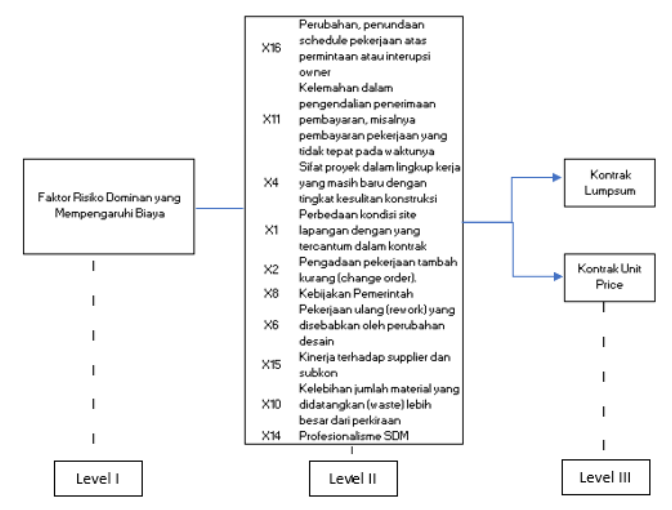

Source: Author's Processed Results, 2019

Figure 3 Risk Factor Hierarchy Structure Cost Aspects

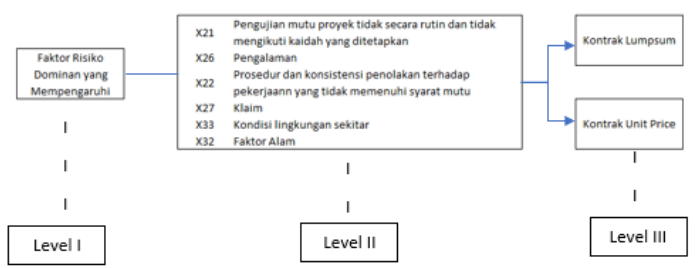

Source: Author's Processed Results, 2019

Figure 4 Quality Factor Hierarchy Structure Quality Aspects

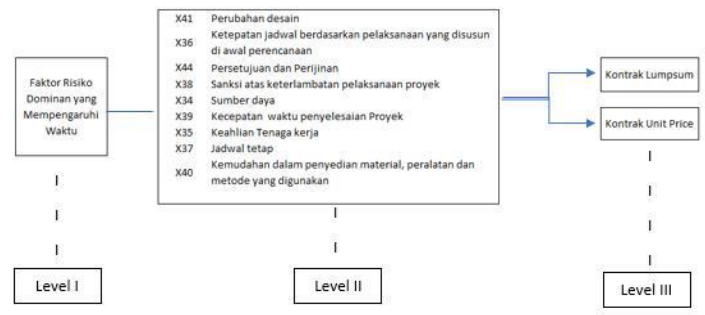

Source: Author's Processed Results, 2019

Figure 5 Hierarchical Structure of Risk Factors in Time Aspects

\section{Calculation of Criteria Weight}

From the results of the calculation of the pairwise comparison matrix and the normality matrix, it is found that the dominant risk factors that affect the aspects of cost, time and quality in lump sum contracts and unit price contracts are based on the weight of each criterion as shown in the following tables. 


\section{VOLUME 2 | NUMBER 2 | MARCH 2020}

Available online at

http://proceedings.worldconference.id.

Table 3: Risk Factors for Dominant Lumpsum Contracts and Unit Price Contracts

\begin{tabular}{|c|l|c|c|r|}
\hline Ienis Kontrak & Aspek & Variabel & $\begin{array}{c}\text { Bobett } \\
\text { Kriteria }\end{array}$ & $\begin{array}{c}\text { Bobst } \\
\text { Bresentase }\end{array}$ \\
\hline \multirow{3}{*}{ Lumpsum } & Biava & $\mathrm{X} 16$ & 0,4608 & $46,08 \%$ \\
\cline { 2 - 5 } & Mutu & $\mathrm{X} 21$ & 0,3754 & $37,54 \%$ \\
\cline { 2 - 5 } & Waktu & $\mathrm{X} 41$ & 0,4579 & $45,79 \%$ \\
\hline \multirow{3}{*}{ Unit Price } & Biava & $\mathrm{X} 8$ & 0,4608 & $46,08 \%$ \\
\cline { 2 - 5 } & Mutu & $\mathrm{X} 22$ & 0,3135 & $31,35 \%$ \\
\cline { 2 - 5 } & Waktu & $\mathrm{X} 39$ & 0,4196 & $41,96 \%$ \\
\hline
\end{tabular}

Source: Author's Processed Results, 2019

\section{Matrix Normalization and Consistency Calculation}

The normalization matrix is a reflection of the paired matrix. In the normalization matrix there is a sum of variables and averages or eigenvectors to produce lamda values, hierarchical Iconsistency ratios and hierarchical consistency indices. In calculating the AHP method, data validity testing is performed using a consistency ratio (CR) with a $10 \%$ consistency limit or in other words $\mathrm{CR} \leq 0.1$.

Table 4 Consistency Ratio

\begin{tabular}{|l|c|c|}
\hline \multirow{2}{*}{ Kriteria } & \multicolumn{2}{|c|}{ CR } \\
\cline { 2 - 3 } & Lumpsum & Unit Price \\
\hline Biava & 0,093750197 & 0,080916567 \\
\hline Mutu & 0,073005683 & 0,047588617 \\
\hline Waktu & 0,055751663 & 0,080705442 \\
\hline
\end{tabular}

Source: Author's Processed Results, 2019

From the calculation of the global priority weighting aspects of cost, time and quality, the final result is that the unit price contract has a greater weighting percentage than the lump sum contract with a ratio of $52.01 \%$ : $47.99 \%$ as shown in the table.

Table 5 Global Priority Weight Recap of Lumpsum Contracts and Unit Price Contracts

\begin{tabular}{|c|c|c|c|c|c|c|c|}
\hline $\begin{array}{c}\text { bobet } \\
\text { kriteria } \\
\text { resike }\end{array}$ & Biava & Mutur & Waktu & $\begin{array}{c}\text { Lumlah } \\
\text { Baris }\end{array}$ & $\begin{array}{c}\text { Bobet } \\
\text { Alternatif }\end{array}$ & Presentasi & Rangking \\
\hline $\begin{array}{c}\text { Kontrak } \\
\text { Lumpsum }\end{array}$ & 0,4608 & 0,3754 & 0,4579 & 1,2941 & 0,4313704 & 52,012761 & 1 \\
\hline $\begin{array}{c}\text { Kontrak } \\
\text { Unit } \\
\text { Price }\end{array}$ & 0,4608 & 0,3135 & 0,4196 & 1,1940 & 0,3979846 & 47,987239 & 2 \\
\hline
\end{tabular}

Source: Author's Processed Results, 2019

\section{Conclussion}

Based on the results and discussion of this study. Then, a conclusion can be drawn from the research on the Risk Management of lump sum contracts and unit price contracts as follows:

1. The results of the analysis using the AHP method show that in construction projects in Bekasi City, the risk factor for using Lumpsum contracts is higher than the Unit Price contracts with a ratio of $52.01 \%$ : $47.99 \%$. From these results it is recommended that the contractor pay more close attention to the dominant risk factors identified before entering the tender process or prior to signing the contract as consideration for anticipating risks and avoiding project cost overruns, delays in project completion time and quality of the resulting project so as not to cause losses the bigger. 
